\title{
Pentingnya Menumbuhkan Kedisiplinan dalam Mencintai Lingkungan bagi Peserta Didik Di SMP Negeri 2 Gatak Menuju Sekolah Adiwiyata
}

\author{
Yeniar Elka Pramesiana ${ }^{1)}$, Aning Fitriani' ${ }^{2)}$, Abdillah Nugroho ${ }^{3)}$ \\ 1,2,3)Universitas Muhammadiyah Surakarta \\ yeniarelka@gmail.com \\ doi: 10.23917/blbs.v2i1.11615
}

\begin{abstract}
Abstrak. Adiwiyata merupakan program pemerintahan dalam rangka menyukseskan pendidikan pembangunan berkelanjutan, bertujuan untuk mewujudkan warga sekolah yang bertanggung jawab serta cinta lingkungan dalam upaya perlindungan dan pengelolaan lingkungan hidup melalui tata kelola sekolah dengan kedisiplinan yang baik. Hal ini sebagaimana yang dilakukan oleh SMP Negeri 2 Gatak. Penelitian ini dilakukan untuk mengobservasi kedisiplinan dalam mencintai lingkungan bagi peserta didik di SMP Negeri 2 Gatak dalam mengimplementasikan program Adiwiyata. Penelitian menggunakan pendekatan deskriptif kualitatif. Data yang diambil bersumber dari data primer serta data sekunder. Teknik pengumpulan data dari observasi, wawancara, dan dokumentasi. Analisis data dikumpulkan pada saat dan setelah pengumpulan data yang meliputi reduksi dan penyajian data. Hasil menunjukan bahwa kedisiplinan dalam mencintai lingkungan oleh peserta didik di SMP Negeri 2 Gatak sudah menuju sekolah Adiwiyata dengan bentuk melakukan kegiatan rutin, kegiatan spontan, keteladanan, dan pengkondisian.
\end{abstract}

Kata Kunci: Adiwiyata, Cinta Lingkungan, Kedisiplinan

\section{PENDAHULUAN}

Pendidikan dan kedisiplinan merupakan bagian utuh dari sebuah proses dan dilakukan secara bersama-sama dalam suatu kegiatan. Pendidikan dapat mencapai hasil maksimal jika dilakukan dalam koridor kedisiplinan yang tinggi. Pendidikan merupakan cara yang tepat dalam membentuk individu yang menanamkan sikap disiplin dan mandiri dalam kehidupan seharihari. Dalam Pasal 3 Undang-Undang Republik Indonesia Nomor 20 tahun 2003 tentang Sistem Pendidikan Nasional menyatakan pendidikan nasional berfungsi untuk mengembangkan kemampuan dan membentuk watak serta peradaban bangsa yang bermartabat dalam rangka mencerdaskan kehidupan bangsa, bertujuan untuk berkembangnya potensi peserta didik agar menjadi manusia yang beriman dan bertakwa kepada Tuhan Yang Maha Esa, berakhlak mulia, sehat, berilmu, cakap, kreatif, mandiri, dan menjadi warga negara yang demokratis serta bertanggung jawab. Dengan membiasakan disiplin di lingkungan sekolah dapat membantu 
peserta didik untuk menjadi individu yang lebih mandiri dan dapat meraih kesuksesan di masa yang akan datang. Berdasakan penelitian yang telah dilakukan diketahui bahwa negara Indonesia merupakan negara ke-2 penghasil sampah di dunia. jawab dalam upaya perlindungan dan pengelolaan lingkungan hidup melalui tata kelola sekolah yang baik untuk mendukung pembangunan berkelanjutan. Untuk mewujudkan tujuan program Adiwiyata tersebut maka dibutuhkan kerja sama seluruh warga sekolah. Melalui pembiasaan kebersihan lingkungan, maka secara tidak langsung hal tersebut dapat menumbuhkan kedisiplinan dalam mencintai lingkungan bagi peserta didik di SMP Negeri 2 Gatak menuju sekolah Adiwiyata.

Penulis mengangkat judul ini karena masih adanya peserta didik yang membuang sampah sembarangan padahal sudah ada himbauan untuk tivak membuang sampah sembarangan dan mencintai lingkungan. Jadi penulis merumuskan masalah sebagai berikut: Bagaimana sikap kedisiplinan dalam mencintai lingkungan bagi peserta didik di SMP Negeri 2 Gatak menuju sekolah Adiwiyata? Mengapa terjadi kurangnya kedisiplinan dalam mencintai lingkungan bagi peserta didik di SMP Negeri 2 Gatak menuju sekolah Adiwiyata? Bagaimana cara mengatasi kurangnya kedisiplinan dalam mencintai lingkungan bagi peserta didik di SMP Negeri 2 Gatak menuju sekolah Adiwiyata?

Tujuan penelitian ini yaitu (1) Mengetahui sikap kedisiplinan dalam mencintai lingkungan bagi peserta didik di SMP Negeri 2 Gatak menuju sekolah Adiwiyata, (2) Mengetahui faktor penyebab kurangnya kedisiplinan dalam mencintai lingkungan bagi peserta didik di SMP Negeri 2 Gatak menuju sekolah Adiwiyata, dan (3) Mengetahui cara mengatasi kurangnya kedisiplinan dalam mencintai lingkungan bagi peserta didik di SMP Negeri 2 Gatak menuju sekolah Adiwiyata.

\section{METODE PENELITIAN}

Penelitian ini dilaksanakan selama 12 hari, kami menggunakan metode deskriptif kualitatif dengan menekankan pada fakta dilapangan dan memberikan gambaran secara jelas. Data yang diambil bersumber dari data primer yang meliputi kepala sekolah, guru, peserta didik yang berlangsung diperoleh dari lapangan serta data sekunder yang diperoleh dari pengumpulan sumber tertulis dan dokumen yang sesuai dengan 
tema kajian. Teknik pengumpulan data dari observasi, wawancara, dan dokumentasi. Analisis data dikumpulkan pada saat dan setelah pengumpulan data yang meliputi reduksi dan penyajian data. Penggambaran yang jelas dilakukan melalui wawancara subjek yang diteliti yakni peserta didik Kelas VII F, VIII H, dan IX F di SMP Negeri 2 Gatak. Melalui hasil wawancara dan data maka ditarik kesimpulan yang kemudian disesuaikan dengan keadaan lapangan.

\section{HASIL PENELITIAN DAN PEMBAHASAN}

1. Sikap Kedisiplinan dalam Mencintai Lingkungan bagi Peserta

Didik di SMP Negeri 2 Gatak menuju Sekolah Adiwiyata

Disiplin adalah suatu kondisi yang tercipta dan terbentuk melalui proses dari serangkaian perilaku yang menunjukkan nilainilai ketaatan, kepatuhan, kesetiaan, keteraturan dan ketertiban. Disiplin akan membuat seseorang tahu dan dapat membedakan hal-hal apa yang seharusnya dilakukan, yang wajib dilakukan, yang boleh dilakukan, yang tak sepatutnya dilakukan (karena merupakan hal-hal yang dilarang). Bagi orang yang disiplin, karena sudah menyatu dalam dirinya, maka sikap atau perbuatan yang dilakukan bukan lagi dirasakan sebagai beban, namun sebaliknya akan membebani dirinya apabila ia tidak berbuat disiplin. Nilai-nilai kepatuhan telah menjadi bagian dari perilaku dalam kehidupannya. Disiplin yang mantap pada hakikatnya akan tumbuh dan terpancar dari hasil kesadaran manusia. Kedisiplinan tidak hanya sebatas ditanamkan, tetapi perlu diimplementasikan dalam kehidupan sehari-hari peserta didik di SMP Negeri 2 Gatak. Kedisiplinan juga harus dilakukan dalam mencintai lingkungan. Namun peserta didik di SMP Negeri 2 Gatak ini masih kurang dalam mengimplementasikan keDisiplinan mencintai lingkungan. Hal tersebut dibuktikan dengan masih adanya sampah yang berceceran, tong sampah yang tidak tertata, kurangnya merawat tanaman, serta kurangnya penggunaan barang-barang untuk memperindah lingkungan.

2. Faktor Penyebab Kurangnya Kedisiplinan dalam Mencintai

Lingkungan bagi Peserta Didik di SMP Negeri 2 Gatak menuju

Sekolah Adiwiyata

SMP Negeri 2 Gatak adalah sekolah yang mempunyai visi berakhlak mulia, unggul dalam prestasi, berwawasan lingkungan 
berlandaskan iman dan taqwa. Salah satu indikator visinya yaitu membangun budaya peduli terhadap kelestarian lingkungan hidup. Tiga dari keenam misi sekolah ini yang menuju sekolah Adiwiyata yaitu meningkatkan budaya disiplin dan tanggung jawab dalam kehidupan sekolah; meningkatkan wawasan akan pentingnya menjaga kelestarian lngkungan; serta membiasakan hidup bersih, sehat, serta kepedulian terhadap kelestarian lingkungan. Sekolah ini juga memiliki tujuan membangun budaya hidup bersih dan sehat serta membangun budaya peduli terhadap kelestarian lingkungan hidup.

Faktor-faktor penyebab kurangnya Kedisiplinan dalam Mencintai Lingkungan bagi Peserta Didik di SMP Negeri 2 Gatak yaitu kurangnya kesadaran peserta didik dalam membuang sampah pada tempatnya, kurangnya kesadaran dalam menata tong sampah, serta kurangnya penggunaan fasilitias dan barangbarang untuk memperindah serta melestarikan lingungan.

3. Cara mengatasi kurangnya kedisiplinan dalam mencintai lingkungan bagi peserta didik di SMP Negeri 2 Gatak menuju sekolah Adiwiyata

Bentuk kegiatan rutin yang dilaksanakan sekolah dalam mengatasi kurangnya kedisiplinan dalam mencintai lingkungan adalah piket harian dan kegiatan kebersihan pagi meliputi kegiatan membersihkan dan merawat lingkungan sekolah. Pada saat piket pagi, peserta didik yang bertugas piket membersihkan dan merapikan ruang kelas. Peserta didik membersihkan dan merapikan ruang kelas dengan cara menyapu, mengepel, menata meja dan kursi, serta menata buku literasi yang ada di kelas masing-masing. Peserta didik yang bertugas piket juga membersihkan lingkungan sekitar kelas.

Budaya sekolah yang dikembangkan dalam pelaksanaan pendidikan cinta lingkungan ditinjau dari beberapa aspek, yang pertama berkaitan dengan program yang disusun sekolah dalam melaksanakan pendidikan cinta lingkungan. Menurut kepala sekolah, program yang disusun dalam pelaksanaan pendidikan cinta lingkungan yaitu dengan cara memasukkan aspek Adiwiyata dalam Rencana Kerja dan Anggaran Sekolah, memasukkannya dalam Rencana Pelaksanaan Pembelajaran setiap bidang mata pelajaran, mewujudkan kantin yang bebas dari makanan yang berbungkus plastik, mengadakan edufarm, gerakan pungut 
sampah setiap hari Selasa s.d. Sabtu selama 15 menit, serta jum'at bersih yang diadakan setiap bulan.

Pengembangan budaya sekolah dalam melaksanakan pendidikan cinta lingkungan, menurut kepala sekolah tidak terlepas dari hadiah dan hukuman yang diterapkan sekolah. Sekolah memberikan hukuman berupa teguran dan peringatan. Hukuman diberikan kepada peserta didik sesuai kemampuan peserta didik. Hadiah yang diberikan sekolah baru sebatas lisan.

Hal spontan yang dilakukan oleh kepala sekolah dan guru ketika ada peserta didik yang berperilaku kurang baik terhadap fasilitas atau lingkungan sekolah adalah dengan mengingatkan dan memberikan teladan. Guru senantiasa untuk mengajak kepada peserta didik untuk menjaga dan merawat fasilitas dan lingkungan sekolah. Misalnya guru mengingatkan peserta didik yang membuang sampah sembarangan.

Menumbuhkan kedisiplinan dalam mencintai lingkungan tidak terlepas dari motivasi yang diberikan kepala sekolah maupun guru kepada peserta didik, agar peserta didik senantiasa mencintai lingkungan. Kepala sekolah dan guru senantiasa memberikan motivasi kepada peserta didik untuk senantiasa mencintai lingkungan. Peserta didik yang menjadi objek dari motivasi yang diberikan oleh kepala sekolah dan guru menyatakan bahwa kepala sekolah dan guru senantiasa memberikan motivasi untuk mencintai lingkungan.

Kepala sekolah dan guru memberi peringatan kepada peserta didik yang merusak tanaman di halaman sekolah. Guru memberikan peringatan kepada peserta didik yang membuang sampah sembarangan. Guru memberikan peringatan dan pemahaman kepada peserta didik untuk tidak merusak tanaman. Kepala sekolah dan guru memberikan apresiasi kepada peserta didik yang rajin piket kelas.

Guru memberikan apresiasi dan sanjungan kepada peserta didik yang rajin membersihkan ruang dan teras kelas. Guru membersikan apresiasi dan sanjungan kepada peserta didik yang rajin merawat dan menyiram tanaman.

\section{SIMPULAN}

Berdasarkan observasi, wawancara dan dokumentasi yang telah dilakukan, maka dapat disimpulkan bahwa sikap kedisiplinan dalam mencintai lingkungan bagi peserta didik di 
SMP Negeri 2 Gatak menuju sekolah Adiwiyata masih kurang, faktor penyebab kurangnya kedisiplinan dalam mencintai lingkungan bagi peserta didik di SMP Negeri 2 Gatak menuju sekolah Adiwiyata yaitu akibat kurangnya kesadaran peserta didik, cara mengatasi kurangnya kedisiplinan dalam mencintai lingkungan bagi peserta didik di SMP Negeri 2 Gatak menuju sekolah Adiwiyata dilakukan dalam bentuk menerapkan kegiatan rutin, hal spontan, serta budaya sekolah oleh peserta didik dengan arahan guru dan kepala sekolah.

\section{DAFTAR PUSTAKA}

Bahrul, Bayu. 2019. Ini Dia 5 Negara Penghasil Sampah Plastik Terbesar di Dunia, Indonesia Peringkat Dua!. Diakses dari https://loop.co.id/articles/negara-penghasil-sampah-plastik/full

Febriati, Rani. 2017. Implementasi Kedisiplinan Dalam Membentuk Sikap Peduli Lingkungan Pada Siswa Kelas IV $S$ Negeri 111/1 Muara Bulian. Jambi: Universitas Jambi.

Republik Indonesia. 2003. Undang-Undang No. 3 Tahun 2003, No. 3. Jakarta: Sekretariat Negara.

Saryanto. 2014. Pelaksanaan Pendidikan Cinta Lingkungan Di Sekolah Dasar Negeri Piyaman I Wonosari Gunungkidul Yogyakarta. Yogyakarta: Universitas Negeri Yogyakarta.

Sunarto, Elia. 2015. Menigkatkan Kepedulian Anak Terhadap Lingkungan Melalui Program Adiwiyata. Diakses dari https://eliasunarto.wordpress.com/2015/01/25/meningka tkan-kepedulian-anak-terhadap-lingkungan-melaluiprogram-adiwiyatal 